\title{
ПСИХОЛОГІЧНІ ОСОБЛИВОСТІ ТА НАУКОВО-ДОСЛІДНА КОМПЕТЕНТНІСТЬ У ФОРМУВАННІ МАЙБУТНІХ ЛІКАРІВ-СТОМАТОЛОГІВ
}

\author{
Н. С. Гутор, А. Б. Бойків \\ ДВНЗ “Тернопільський державний медичний університет \\ імені I. Я. Горбачевського МОЗ Украӥни"
}

\section{PSYCHOLOGICAL FEATURES AND SCIENTIFIC-EXPERIMENTAL COMPETENCE IN FORMING OF FUTURE DOCTORS-DENTISTS}

N. S. Hutor, A. B. Boikiv

SHEI "Ternopil State Medical University by I. Ya. Horbachevsky of MPH of Ukraine”

\begin{abstract}
У статті розкривається досвід професійної підготовки майбутніх лікарів-стоматологів на кафедрах хірургічної та дитячої стоматології з урахуванням психологічних особливостей студента, що є невід'ємною складовою у формуванні спеціаліста, створюється резерв як медичних, так і педагогічних кадрів.
\end{abstract}

The article opens the experience of professional preparation of future doctors-dentists on the departments of surgical and child dentistry taking into account psychological features of student, which are an inalienable constituent in forming of specialist, reserve of both medical and pedagogical shots is created.

Вступ. На сучасному етапі розвитку суспільства загострюються питання поєднання медицини та психології, що підкреслює важливість проблеми культури медичного обслуговування (взаємозв'язок надання медичної допомоги з емоційним комфортом хворих). Розуміння та сприйняття лікарем-стоматологом пацієнтів, взаємовідносини лікар - пацієнт - родичі пацієнта - медперсонал - колеги інших медичних закладів, своєрідність типів характеру хворих - усе це формується в процесі спілкування [1-3].

Вивчення психологічних особливостей хворих пов'язані зі здатністю лікаря поставити себе на місце пацієнта, побачити, відчути, зрозуміти його стан. Даний аналіз має не тільки теоретичне, а й велике практичне значення, що дозволяє стверджувати про необхідність підвищення психологічної компетентності майбутніх лікарів-стоматологів [4-10].

Основна частина. Основною метою педагогічного процесу у вищому навчальному медичному закладі є підготовка висококваліфікованих лікарів-стоматологів, з урахуванням психологічних особливостей студента створити резерв як медичних, так $\mathrm{i}$ педагогічних кадрів.

Під час навчання студентів стоматологічного факультету у ДВНЗ “Тернопільський державний медич-

() Н. С. Гутор, А. Б. Бойків ний університет імені І. Я. Горбачевського МОЗ України" здійснюється професійна адаптація майбутнього спеціаліста. Особливо важливу роль відіграє високоякісна підготовка лікарів-стоматологів, основною ознакою якої є навчити аналітичного мислення та застосування наукових розробок у практичній сфері діяльності і формування лікаря як особистості та майбутнього вченого.

На кафедрах хірургічної та дитячої стоматології вмінню спілкуватися викладачі приділяють увагу на практичних заняттях, на лекціях, під час виробничої практики, тобто під час роботи з пацієнтами, оскільки постановка правильного діагнозу та вибір адекватного методу лікування - це складний процес, який потребує відповідних досліджень, врахування багатьох факторів та знань, які часом виходять за рамки навчальної програми та потребують навичок саме дослідницької роботи. Якщо студент зможе наблизитися до визначення можливої причини хвороби пацієнта та знайти відповідні методи лікування, він робить великий крок у набутті власного клінічного досвіду, розвитку своєї клінічної та науково-дослідної компетентності.

Найбільш активно науково-дослідна робота проводиться зі студентами 4 курсу стоматологічного факультету. Спрямування студентів до наукової робо- 
ти, важливість розгляду змісту, умов формування дослідження, оцінка результатів, значення науководослідної роботи - усе це є складовими компетентнісно-орієнтованої освіти в процесі набуття нових знань. Вона забезпечує творче застосування навчального матеріалу на практиці й перехід від навчально-пізнавальної до самостійної творчої професійної діяльності, мотивації до навчання протягом усього життя, до саморозвитку та самовдосконалення, пошуку впровадження наукових досліджень у практичну клінічну роботу, бажання донести результати своєї наукової роботи широкій аудиторії, співпрацювати, а не ставати конкурентами. Дуже важливим робити висновки щодо проведених досліджень лише на засадах доказової медицини.

3 боку викладачів кафедр робота має бути направлена на активізацію та розуміння важливості розвитку науково-дослідної компетентності у майбутніх фахівців. Викладач має вміти зацікавити та професійно керувати студентською науковою роботою.

Успішне психологічне забезпечення навчальновиховного процесу великою мірою залежить від ефективності підготовки молодих кадрів. Враховуючи те, що гуманність медичної праці беззаперечна, тому завжди актуальною є проблема психологічної та деонтологічної підготовки студентів стоматологічного факультету, бо саме у процесі професійного становлення закладаються основи моральності майбутнього лікаря-стоматолога. Слід враховувати й емоційний досвід лікаря-стоматолога та його взаємодію із хворими, специфіку лікування та спілкування під час надання лікарської допомоги.

На семінарських заняттях увага студентів-стоматологів акцентується на розкриття специфіки процесу становлення та формування психотерапевтичних та деонтологічних вмінь. Усі ці заходи направлені на профілактику появи як особистих, так і професійних деформацій у майбутніх лікарів-стоматологів.

Висновок. Професійна підготовка майбутніх лікарів-стоматологів має базуватися на теоретичних знаннях та практичному вмінні викладача використовувати психологічні особливості студента для формування основ моральності та науково-дослідної компетентності, що є невід'ємною складовою у формуванні спеціаліста, створюється резерв як медичних, так і педагогічних кадрів.

\section{Література}

1. Луговий В. І. Вища освіта через дослідження: конщептуальні засади здійснення й оцінювання / В. І. Луговий, Ж. В. Таланова // Вища освіта України. Тематичний випуск "Педагогіка вищої школи: методологія, теорія, технології”. -2012.-Т. 1.-С. 16-28.

2. Кондрашихін А. Б. Шляхи активізації інноваційної творчої діяльності у вищих закладах освіти / А. Б. Кондрашихін // Проблеми освіти. -2011.-№ 66.-С. 29-34.

3. Шадриков В. Д. Новая модель специалиста: инновационная подготовка и компетентностный подход / В. Д. Шадриков // Высшее образование сегодня. - 2004. - № 8. C. $26-31$.

4. Борисенко Л. Л. Психолого-педагогічні аспекти управління науково-дослідною роботою студентів економічних спеціальностей / Л. Л. Борисенко // Проблеми освіти. 2012.-№ 70.-С. 18-23.

5. Кравченко Ю. М. Проблеми організації науково-дослідної діяльності студентів у вузі / Ю. М. Кравченко // Проблеми освіти. - 2010. - № 63. - С. 62-63.

6. Луценко Г. В. Компетентнісний підхід до науково-дослідної роботи студентів як елемент фундаменталізації

фізичної освіти / Г. В. Луценко // Вища освіта України. Тематичний випуск "Педагогіка вищої школи: методологія, теорія, технології”. -2012.- Т. 3.-С. 80-89.

7. Майборода В. К. Проблеми розвитку праксеологічних умінь майбутніх компетентних фахівців вищої школи України / В. К. Майборода // Вища освіта України. -2012. №4.-C.31-36.

8. Микитюк О. М. Теорія та практика організації науководослідної роботи у вищих закладах освіти України в XIX ст. : автореф. дис. доктора педагогічних наук: 13.00.01 “Загальна педагогіка та історія педагогіки” / О. М. Микитюк. -К., 2004. -42 с.

9. Сгадова В. В. Підготовка майбутнього вчителя до науково-дослідної роботи / В. В. Сгадова // Проблеми освіти. 2010. -№63. -С. 64-69.

10. Фролова М. Е. Педагогічне забезпечення процесу формування дослідницьких компетентностей студентів в системі вищої економічної освіти / М. Е. Фролова // Вища освіта України. Тематичний випуск "Педагогіка вищої школи: методологія, теорія, технології”. -2012.- Т. 3.-С. 206216.

Отримано 04.08.14 